\title{
PERTUMBUHAN DAN KELANGSUNGAN HIDUP BENIH IKAN NILA (OREOCHROMIS NILOTICUS) PADA PAKAN BUATAN YANG BERBEDA
}

\author{
Abdul Rachman Niode, Nasriani, Ad Mahmudy Irdja \\ Program Studi Budidaya Perairan Universitas Muhammadiyah Gorontalo \\ Gorontalo 9600, Indonesia \\ Mamanniode86@gmail.com,nasriani_syam@yahoo.com,adirdja@yahoo.com
}

\begin{abstract}
This research was conducted at the Fish Seed (BBI) Gorontalo. The purpose of this study was to determine the effect of different artificial feeding on the growth and survival of tilapia fish (Oreochromis niloticus) and determine the proper feed for tilapia fish. This research uses experimental methods and applied using a completely randomized design (CRD) with 4 treatments and 3 replications. Analysis of the growth data using analysis of variance (ANOVA), if the results are significantly different then continued with LSD (least significant difference). The results showed that each of the feed given to tilapia fish give a different effect. Absolute growth of tilapia fish feed given $A, B, C$ and $D$ in terms of absolute length growth is $0: 35+3: 07,3: 39+0.4,0.61+3.89$, and $0: 26+2.63 \mathrm{~cm}$, while the growth in the absolute weight of each feed is feed $A$ at 1:16+4:05, 1:45+4.5gram feed $B, C 1.85+$ $4.99 \mathrm{gram}$ feed, and feed $D 0.82+3.34 \mathrm{gram}$. As for the survival of tilapia fish in each feed $A$, $B, C$ and $D$ at $73.33 \%, 84.44 \%, 91.11 \%$ and $68.89 \%$. Feed which resulted in the growth and survival of the greatest tilapia fish (Oreochromis niloticus) is feed C (PF-1000)
\end{abstract}

Keywords: Tilapia, feed, growth

\begin{abstract}
Abstrak
Pakan adalah faktor yang berpengaruh terhadap pertumbuhan ikan. Oleh karena itu, dalam penelitian ini akan dilihat pengaruh pemberian pakan buatan yang berbeda terhadap pertumbuhan dan kelangsungan hidup benih ikan nila (Oreochromis niloticus) serta menentukan pakan yang tepat. Penelitian ini menggunakan metode eksperimen dan diaplikasikan menggunakan Rancangan Acak Lengkap (RAL) dengan 4 perlakuan dan 3 ulangan. Analisis data menggunakan analysis of variance (ANOVA) dan uji BNT. Hasil penelitian menunjukkan bahwa tiap pakan memberikan pengaruh yang berbeda-beda. Pertumbuhan panjang mutlak benih ikan nila yang diberi pakan $A, B, C$ dan $D$ adalah $0.35 \pm 3.07,0.4 \pm 3.39,0.61 \pm 3.89$, dan $0.26 \pm 2.63 \mathrm{~cm}$, sedangkan berat mutlak pada pakan $\mathrm{A}$, $B$, C, dan $D$ adalah sebesar $1.16 \pm 4.05,1.45 \pm 4.5,1.85 \pm 4.99$, dan 0.82+3.34gram. Sementara untuk kelangsungan hidup pada masing-masing pakan $A, B, C$ dan $D$ sebesar $73.33 \%, 84.44 \%, 91.11 \%$ dan $68.89 \%$. Pakan yang menghasilkan pertumbuhan dan kelangsungan hidup terbaik bagi benih ikan nila (Oreochromis niloticus) adalah pakan C (PF1000).
\end{abstract}

Kata kunci: Ikan Nila, Pakan, Pertumbuhan 


\section{PENDAHULUAN}

Indonesia dikenal memiliki kekayaan sumberdaya perikanan yang cukup besar, terutama tentang jenis ikan. Menurut Amri (2007), diperkirakan sekitar 167 ribu spesies ikan yang ada di dunia hidup di perairan Indonesia. Jenis ikan tersebut tidak hanya ikan air laut, melainkan ikan air tawar. Ikan air tawar merupakan jenis ikan yang hidup di perairan daratan. Di Indonesia, terdapat beberapa jenis ikan air tawar yang sudah dibudidayakan oleh masyarakat. Ikan air tawar selain memiliki nilai gizi yang tinggi juga memiliki nilai ekonomis tinggi untuk diperdagangkan, salah satunya yaitu ikan nila (Oreochromis niloticus).

Ikan nila (Oreochromis niloticus) adalah salah satu ikan air tawar yang banyak dibudidayakan karena mudah beradaptasi dengan lingkungan yang kurang menguntungkan dan mudah dipijahkan, sehingga penyebarannya di alam sangat luas, baik di daerah tropis maupun di daerah beriklim sedang (Angienda et al., 2010). Pada tahun 2004 produksi ikan nila tercatat sebesar 97116 ton, meningkat sebesar $237 \%$ dalam kurun waktu 4 tahun (Gustiano et al., 2003).

Ikan nila telah lama dikembangkan sebagai komoditi ekspor baik dalam bentuk ikan utuh maupun dalam bentuk fillet. Negaranegara pengekspor ikan nila antara lain China, Ekuador, Kuba, Honduras, dan juga Indonesia. Adapun negaranegara yang tercatat sebagai pengimpor ikan nila antara
lainSingapura, Jepang dan Amerika Serikat. Kebutuhan ikan nila di Amerika Serikat cukup tinggi sedangkan produksi nila domestik belum dapat memenuhi kebutuhannya. Pada tahun 1998 impor nila Amerika Serikat dari manca negara mencapai 45 ton dan pada tahun 1999 meningkat lagi $15 \%$ atau sekitar 52 ton (Amri, 2007).

Di Indonesia, ikan nila merupakan komoditas unggulan dan pembudidayaannya berkembang cukup baik. Ikan nila merupakan ikan yang banyak diminati masyarakat sebagai sumber protein hewani berkolesterol rendah denaan kandungan gizi $17,7 \%$ proteir

1.3\% lemak (Sumiarti 2000 vaıaı! Wijaya 2011).

Pakan merupakan salah satuatu aspek penting yang harus diperhatikan dalam kegiatan budidaya, sebab pakan merupakan sumber energi untuk menunjang pertumbuhan. Pakan yang baik adalah pakan yang sesuai dengan kebutuhan fisiologi dan spesies ikan yang dibudidayakan. Disamping mampu untuk memenuhi kebutuhan nutrisi ikan tersebut, pemberian pakan dengan kualitas dan kuantitas yang baik dapat mengoptimalkan usaha budidaya ikan. Pakan harus tersedia dalam jumlah yang cukup, terus menerus (kontinu), dan mempunyai kandungan gizi yang dibutuhkan untuk pertumbuhan ikan (Maskur, 2004).

Pakan ikan terdiri atas pakan alami dan pakan buatan. Pakan alami merupakan pakan awal dan utama bagi benih ikan karena memiliki 
kandungan gizi yang cukup lengkap dan mudah dicerna. Sementara pakan buatan adalah pakan yang dibuat dengan formulasi tertentu berdasarkan pertimbangan pembuatnya. Pembuatan pakan buatan sebaiknya didasarkan pada pertimbangan kebutuhan nutrisi ikan, sumber dan kualitas bahan baku, serta nilai ekonomis. Menurut Heinemans (1986) dan Tjahjo(1988) dalam Almaududy (2006), keuntungan pakan buatan adalah memiliki kandungan gizi yang dapat disesuaikan berdasarkan kebutuhan ikan, lebih tahan lama, dan bentuk serta ukurannya dapat disesuaikan dengan bukaan mulut ikan. Kelemahan pakan buatan adalah respon ikan kurang dan bila formula kurang tepat hanya akan menjadi limbah yang mengotori media lingkungan.

Peningkatan pertumbuhan ikan dapat dilakukan dengan pemberian pakan yang berfungsi sebagai pemasok energi untuk memacu pertumbuhan dan mempertahankan kelangsungan hidup. Salah satu faktor yang harus diperhatikan adalah ketersediaan pakan bagi ikan budidaya baik itu pakan alami maupun pakan buatan yang tersedia secara kualitas dan kuantitas. Salah satu masalah pada usaha budidaya ikanadalah pengadaan pakan yang tidak seimbang dengankebutuhan ikan yang akan mengakibatkan produksiikan tidak optimal.

Pemberian pakan yang tepat sangat berpengaruh besar terhadap pertumbuhan ikan. Jenis pakan yang dikonsumsi dapat berupa pakan alami dan pakan buatan yang mengandung nutrien yang dapat memenuhi kebutuhan ikan. Selain itu pemberian pakan diharapkan dapat menyebabkan keseimbangan pemenuhan gizi oleh ikan.

\section{METODE PENELITIAN}

Penelitian ini dilakukan pada bulan Februari sampai Maret 2016. Penelitian ini bertempat di Balai Benih Ikan (BBI) Kota Gorontalo. Benih yang digunakan berasal dari balai tersebut.

Wadah yang digunakan dalam penelitian adalah wadah plastik berkapasitas sepuluh liter air sebanyak dua belas buah. Wadah tersebut dilengkapi dengan selang aerasi, batu aerasi, dan blower bahan pelengkap tersebut digunakan untuk mensuplai oksigen ke dalam media pemeliharaan benih ikan nila.

Hewan uji yang digunakan dalam penelitian ini adalah benih ikan nila (Oreochromis niloticus) yang diperoleh dari Balai Benih Ikan (BBI) Kota Gorontalo. Benih ikan nila yang digunakan berukuran 4-4,4 cm dengan berat 3,51-3,92 gram sebanyak 180 ekor.

\section{Parameter Pengamatan}

Pertumbuhan Mutlak

1. Pertumbuhan panjang mutlak

Perhitungan pertambahan panjang mutlak benih ikan nila menurut Effendi (1997) dalam Tarigan (2014) adalah sebagai berikut:

$$
\mathrm{L}=\mathrm{L}_{\mathrm{t}}-\mathrm{L}_{0}
$$


Keterangan:

$\mathrm{L}=$ Pertumbuhan panjang mutlak ikan (cm)

$\mathrm{Lt}=$ Panjang ikan pada waktu $\mathrm{t}(\mathrm{cm})$

Lo $=$ Panjang ikan pada awal penelitian $(\mathrm{cm})$

2. Pertumbuhan bobot mutlak

Perhitungan pertambahan bobot mutlak benih ikan nila menurut Effendie (1997) dalam Tarigan (2014) adalah sebagai berikut:

$$
\mathrm{W}=\mathrm{W}_{\mathrm{t}}-\mathrm{W}_{0}
$$

Keterangan:

$\mathrm{W}=$ Pertambahan bobot ikan (gr)

$\mathrm{Wt}=$ Berat akhir ikan pada waktu ke-t (gr)

Wo $=$ Berat awal ikan (gr)

\section{Pertumbuhan Harian}

1. Pertumbuhan panjang harian

$$
\text { Perhitungan Pertambahan }
$$

Panjang Harian atau Average Daily Growth (ADG) menurut Effendie (1997) dalam Tarigan (2014) adalah sebagai berikut:

$$
A D G=\frac{L t-L o}{H}
$$

Keterangan:

$\mathrm{Lt}=$ Panjang akhir $(\mathrm{cm})$

Lo $=$ Panjang awal $(\mathrm{cm})$

$\mathrm{H}=$ Lama pemeliharaan (hari)

2. Pertumbuhan berat harian

Perhitungan Pertambahan Berat Harian atau average daily growth (ADG) menurut Effendie (1997) dalam
Tarigan (2014) adalah sebagai berikut:

$$
A D G=\frac{W t-W o}{H}
$$

Keterangan:

$\mathrm{Wt}=$ Berat akhir (gr)

Wo $=$ Berat awal (gr)

$\mathrm{H}=$ Lama pemeliharaan (hari)

\section{Laju Pertumbuhan Spesifik}

Laju pertumbuhan spesifik atau spesifik growth rate (SGR) hewan uji dihitung menggunakan rumus Zonneveld (1991) dalam Trisnawati (2014):

$$
\mathrm{SGR}=\frac{\ln \mathrm{W}_{\mathrm{t}}-\ln \mathrm{W}_{0}}{\mathrm{t}} \times 100 \%
$$

Keterangan:

SGR = Laju pertumbuhan spesifik (\%)

$\mathrm{Wt}=$ Berat ikan waktu ke-t (gr)

Wo = Berat ikan awal (gr)

$\mathrm{T}=$ Waktu pemeliharaan (hari)

\section{Kelangsungan Hidup}

Kelangsungan hidup atau survival rate (SR) adalah persentase jumlah biota yang hidup pada akhir waktu tertentu. Perhitungan rumus kelangsungan menurut Goddaard (1996) dalam Tarigan (2014) adalah sebagai berikut:

$$
\mathrm{SR}=\frac{\mathrm{N}_{\mathrm{t}}}{\mathrm{N}_{0}} \times 100 \%
$$


Keterangan:

$\mathrm{SR}=$ Tingkat Kelangsungan Hidup (\%)

$\mathrm{Nt}=$ Jumlah Ikan pada waktu ke-t (ekor)

No $=$ Jumlah ikan pada awal penelitian (ekor)

\section{Analisis Data}

Setiap perlakuan diberikan kepada 15 ekor benih ikan nila. Jadi total percobaan pada penelitian ini adalah dua belas satuan percobaan (4 perlakuan 3 kali ulangan). Perlakuan yang diberikan adalah pemberian pellet FF-999, FF-888, PF-1000 dan pelet SINTA dengan komposisi perlakuan yang digunakan adalah sebagai berikut.
1. Pakan A : Pelet FF-999
2. Pakan B : Pelet FF-888
3. Pakan C : Pelet PF-1000
4. Pakan D : Pelet SINTA

Rancangan acak lengkap bertujuan untuk menghomogenkan data sehingga presentase kesalahan menjadi lebih kecil (Sugandi dan Sugiarti, 1993 dalam Wijayanti, 2010). Penetapan tiap ulangan untuk tiap perlakuan bahwa penelitian berdasarkan pada pernyataan Hanafiah (2005) yang menyatakan bahwa penelitian eksperimental minimal dilakukan dengan tiga kali ulangan.

Rancangan acak lengkap yang digunakan untuk mengetahui adanya pengaruh pemberian pakan buatan yang berbeda terhadap pertumbuhan dan kelangsungan hidup benih ikan nila. Menurut Gaspersz (1994), rumusan rancangan acak lengkap adalah sebagai berikut.

$$
Y_{i j}=\mu+\tau_{i}+\varepsilon_{i j}
$$

Keterangan:

$Y_{i j}=$ Pengamatan dari perlakuan ke i ulangan ke $\mathrm{j}$

$\mu=$ Nilai tengah dari seluruh perlakuan

$\tau_{1}=$ Pengaruh perlakuan ke $\mathrm{i}$

$\varepsilon_{\mathrm{ij}}=$ Galat perlakuan ke $\mathrm{i}$ ulangan ke $\mathrm{j}$

$\mathrm{i}=$ Perlakuan $(\mathrm{A}, \mathrm{B}, \mathrm{C})$

$\mathrm{j}=$ Ulangan $(1,2,3)$

\section{HASIL PEMBAHASAN}

\section{Pertumbuhan Panjang Mutlak}

Hasil perhitungan panjang mutlak benih ikan nila (Oreochromis niloticus) sesuai perlakuan pemberian pakan yang berbeda selama 28 hari menunjukkan pertumbuhan panjang mutlak seperti yang terlihat pada Gambar 1.

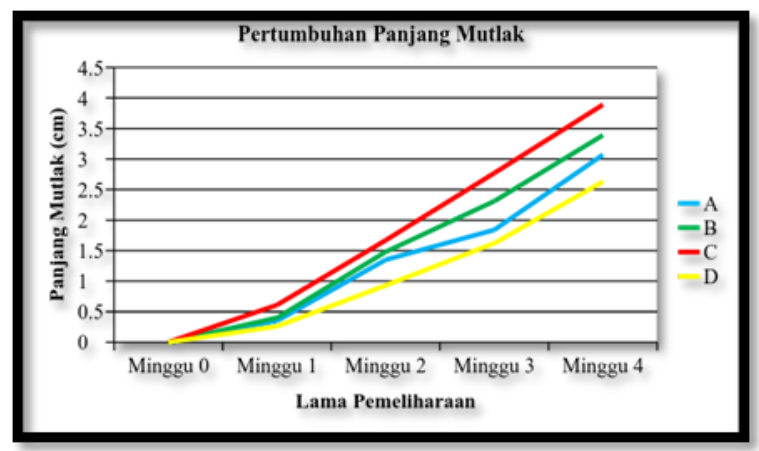

Gambar 1. Grafik pertumbuhan panjang mutlak benih ikan nila 
Gambar 1. Menunjukkan pertumb uhan panjang mutlak benih ikan nila yang diberikan perlakuan pakan buatan yang berbeda. Gambar tersebut menunjukkan bahwa terjadi pertumbuhan panjang mutlak benih ikan nila. Pertumbuhan yang terjadi setiap minggu menunjukkan bahwa pakan yang diberikan sudah mampu diserap dan dicerna ikan untuk dijadikan sebagai kegiatan untuk tumbuh.

Pertumbuhan panjang mutlak tertinggi ditemukan pada benih ikan nila yang diberi perlakuan pakan C (F1000) sebesar $3.89 \mathrm{~cm}$ dibandingkan dengan perlakuan $D$ sebesar $2,63 \mathrm{~cm}$. Perbedaan pertumbuhan panjang mutlak tersebut karena adanya perbedaan komposisi nutrisi pada masing-masing pakan yang digunakan. Menurut Linder (1992), nutrisi merupakan salah satu aspek yang sangat penting dalam budidaya ikan. Beberapa komponen nutrisi yang sangat penting dan harus tersedia dalam pakan ikan antara lain adalah protein, lemak, karbohidrat, vitamin serta mineral. Nutrisi mempunyai pengaruh yang besar terhadap kesehatan, pertumbuhan dan reproduksi ikan. Kekurangan salah satu nutrisi dapat menurunkan laju pertumbuhan, menyebabkan penyakit, sedangkan kelebihan nutrisi dapat menyebabkan laju pertumbuhan terhambat (Marzuqi, 2015).

Kebutuhan nutrisi untuk pertumbuhan ikan berbeda menurut jenis dan ukurannya. Pada nutrisi ikan, protein merupakan komponen organik utama yang bahannya dari jaringan tubuh hewan, $65-75 \%$ protein berperan sebagai sumber energi dan sebagai zat pembangun dan pengatur untuk pertumbuhan. Hal yang sama juga diungkapkan oleh Halver (2002), bahwa protein berperan sebagai sumber berbagai zat yang menentukan pertumbuhan ikan. Berdasarkan nilai komposisi nutrisi pakan yang diberikan dapat diketahui bahwa tingginya pertumbuhan panjang mutlak benih ikan nila yang diberi perlakuan pakan $\mathrm{C}$ disebabkan oleh kandungan protein pada pakan $C$ yang lebih besar dibanding pakan lainnya.

\section{Pertumbuhan Berat Mutlak}

Perlakuan pemberian pakan yang berbeda pada benih ikan nila selama 28 hari menghasilkan rata-rata pertumbuhan berat mutlak yang berbeda. Hal ini dapat dilihat pada Gambar 2 berikut:

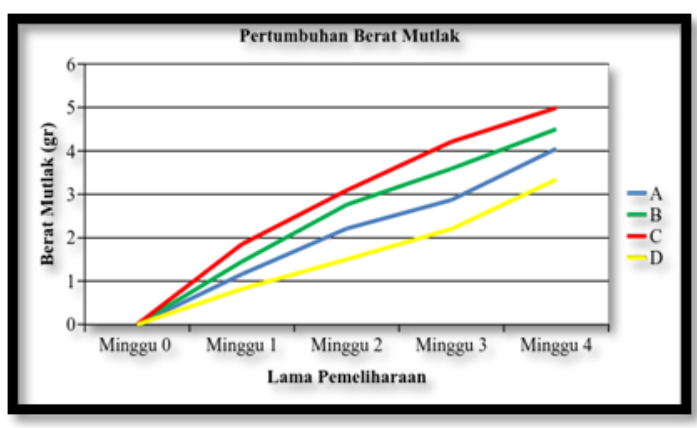

Gambar 2. Grafik pertumbuhan berat mutlak benih ikan nila

(Sumber: Hasil olahan data primer, 2016)

Pertumbuhan berat mutlak benih ikan nila menunjukkan pertambahan 
bobot tubuh ikan nila selama penelitian. Secara keseluruhan pertumbuhan bobot ikan nila mengalami peningkatan pada berbagai perlakuan pemberian pakan. Tingginya pertumbuhan berat mutlak pada benih ikan nila yang diberi pakan $\mathrm{C}$ diduga disebabkan oleh kandungan nutrisi yang cukup optimal yang terdapat dalam pakan. Selain memiliki kandungan protein yang lebih tinggi dibandingkan pakan lainnya, pakan $\mathrm{C}$ juga mengandung lemak dan serat kasar yang lebih banyak. Menurut Meyer dan Pena (2001), kadar protein untuk ikan nila berkisar antara $25-35 \%$. Meskipun kandungan semua pakan yang digunakan dalam penelitian ini sudah lebih dari $25 \%$, dimana pakan A mengandung protein $35 \%$, pakan B 36$38 \%$, dan pakan D $30 \%$ namun ternyata pakan $\mathrm{C}$ dengan kandungan protein sebesar $39-41 \%$ lebih optimal penggunaannya dalam pertumbuhan benih ikan nila.

Selain protein, ikan nila juga membutuhkan karbohidrat dan lemak untuk pertumbuhan. Secara umum karbohidrat yang terdapat dalam pakan dapat berupa serat kasar yang sulit dicerna oleh ikan (Hariadi et al. 2005). Sementara menurut Furuichi (1988), kebutuhan karbohidrat untuk ikan nila berkisar $30-40 \%$. Berdasarkan tabel komposisi kandungan nutrisi pakan $\mathrm{A}$, $B, C$, dan $D$, terlihat bahwa keempat pakan tersebut masih memiliki kandungan karbohidrat yang rendah yaitu dibawah $10 \%$. Sementara untuk kandungan lemak, kandungan dari masing-masing pakan $A, B, C$, dan $D$ adalah 2\%, 2\% 5\%, dan 5\%. Menurut Zonneveld et al., (1991), lemak yang dibutuhkan ikan nila berkisar 5-8,5\%. Berdasarkan hal tersebut dapat diketahui bahwa pakan $C$ dan $D$ yang memiliki kandungan lemak $5 \%$. Namun selain protein, karbohidrat, dan lemak, menurut Yanti et al., (2013), komponen lain yang juga dibutuhkan dalam pakan yaitu vitamin dan mineral dalam jumlah yang kecil, namun kehadirannya dalam pakan juga penting karena dibutuhkan tubuh ikan untuk tumbuh dan menjalani beberapa fungsi tubuh.

\section{Pertumbuhan Harian (ADG)}

Average Daily Gain (ADG) adalah rata-rata pertumbuhan ikan baik dari segi pertambahan panjang maupun beratnya. Berdasarkan hasil pengukuran pertumbuhan harian panjang dan berat benih ikan nila dengan menggunakan pakan F-999, F888, F-1000, dan pakan sinta diperoleh rata-rata pertumbuhan harian seperti pada Tabel 1.

Tabel 1. Rata-rata pertumbuhan panjang dan berat harian benih ikan nila

\begin{tabular}{|c|c|c|}
\hline \multirow{2}{*}{$\begin{array}{c}\text { Perlakua } \\
n\end{array}$} & \multicolumn{2}{|c|}{ Pertumbuhan Harian (ADG) } \\
\hline & $\begin{array}{c}\text { Panjang } \\
(\mathrm{cm})\end{array}$ & Berat (gram) \\
\hline A & 0,11 & 0,15 \\
\hline B & 0,12 & 0,16 \\
\hline C & 0,14 & 0,18 \\
\hline $\mathrm{D}$ & 0,09 & 0,12 \\
\hline
\end{tabular}

Sumber: Hasil olahan data primer, 2016

Berdasarkan data pertumbuhan harian panjang dan berat benih ikan nila terlihat bahwa pertumbuhan berat benih ikan nila lebih tinggi dari 
pertumbuhan panjang. Hal ini menunjukkan bahwa pemberian pakan yang berbeda menghasilkan pertumbuhan berat yang lebih tinggi dibandingkan dengan pertumbuhan panjang. Menurut Islaminingrum (2011) bahwa hubungan panjang dan berat yang terjadi pada ikan, ada yang bersifat allometrik positif yang menunjukkan bahwa pertumbuhan berat ikan lebih cepat dari pada pertumbuhan panjangnya dan allometrik negatif yang menunjukkan pertumbuhan panjang ikan lebih cepat dari pada pertumbuhan beratnya. Pertumbuhan harian panjang dan berat benih ikan nila selama penelitianmenunjukkan angka pertumbuhan yang besar karena dipengaruhi oleh pemberian pakan yang berkualitas tinggi.

Hasil perhitungan pertumbuhan harian rata-rata panjang dan berat menunjukkan bahwa perlakuan $\mathrm{C}$ (pakan PF-1000) memiliki pertumbuhan harian tertinggi kemudian disusul dengan perlakuan $B$ (pakan FF-888), setelah itu perlakuan $A$ (pakan FF-999) dan perlakuan D (pakan sinta) menunjukkan angka pertumbuhan terendah. Arisma (2004) dalam Wijayanti (2010), menyatakan bahwapertumbuhan dipengaruhi oleh sumber energy dari pakan yang tersedia. Sumber energi tersebut berupa karbohidrat, lemak, dan protein. Sumber energi nonprotein (karbohidrat dan lemak) yang tepat dalam pakan dapat mengurangi penggunaan protein sebagai sumber energi (Suhenda dkk, 2003 dalam
Wijayanti (2010). Jika sumber energi nonprotein cukup, maka fungsi protein untuk pertumbuhan dapat terlaksana (Arisma, 2004 dalam Wijayanti, 2010).

\section{Laju Pertumbuhan Spesifik}

Laju pertumbuhan spesifik menunjukkan persentase kenaikan bobot ikan setiap hari selama penelitian (Rahmawati dan Samidjan, 2013). Laju pertumbuhan spesifik benih ikan nila penelitian dapat dilihat pada Gambar 3.

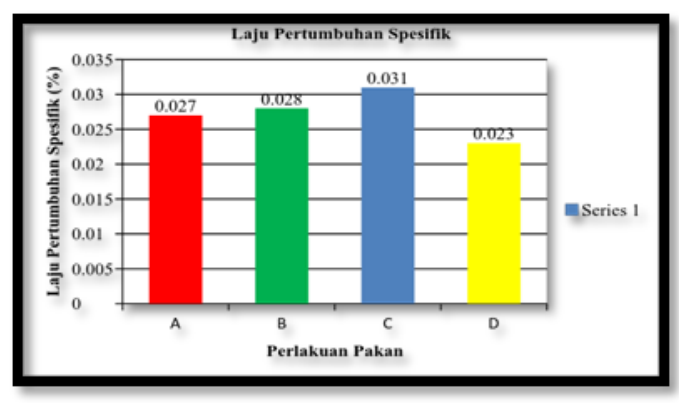

Gambar 3. Laju
$\begin{gathered}\text { pertumbuhan } \\ \text { spesifik } \\ \text { nila }\end{gathered}$

Berdasarkan grafik laju pertumbuhan spesifik dapat dketahui bahwa benih ikan nila yang diberi berbagai perlakuan pakan memiliki laju pertumbuhan spesifik yang yang berbeda-beda.Secara keseluruhan pertambahan bobot tubuh ikan nila mengalami peningkatan pada semua perlakuan pemberian pakan. Menurut Rachmawati dan Samidjan (2013), peningkatan bobot disebabkan karena setiap pakan yang diberikan dapat direspon oleh ikan dan digunakan untuk proses metabolisme dan pertumbuhan. Pertumbuhan dipengaruhi oleh keseimbangan 
nutrient yang terdapat dalam pakan. Hal ini sesuai dengan pernyataan Effendie (1997), bahwa pertumbuhan terjadi apabila terdapat kelebihan energi hasil metabolisme setelah digunakan untuk pemeliharaan tubuh dan aktivitas. Pakan yang dikonsumsi pertama-tama akan digunakan untuk memelihara tubuh dan mengganti selsel yang rusak, selebihnya digunakan untuk pertumbuhan. Hal ini sesuai dengan pernyataan Fujaya (2004), bahwa ikan akan mengkonsumsi pakan hingga akan memenuhi kebutuhan energinya, sebagian besar pakan digunakan untuk proses metabolisme dan sisanya digunakan untuk beraktifitas lain seperti pertumbuhan.

Tingginya laju pertumbuhan spesifik pada benih ikan nila yang diberi pakan $\mathrm{C}$ menunjukkan bahwa pakan $\mathrm{C}$ mengandung komposisi nutrisi yang sesuai dengan kebutuhan nutrisi benih ikan nila untuk tumbuh secara optimal. Menurut Akiyama et al., (1991) dalam Rachmawati Samidjan (2013), ikan dapat tumbuh dengan baik jika asupan nutriennya tercukupi, terutama kebutuhan protein. Kekurangan protein dalam pakan dapat menyebabkan terhambatnya pertumbuhan, diikuti oleh kehilangan bobot tubuh karena pemakaian protein dari jaringan tubuh untuk memelihara fungsi vital. Sementara menurut Mokoginta (2000), tidak hanya protein yang diperlukan untuk pertumbuhan ikan, tetapi lemak. Lemak merupakan salah satu sumber energi yang harus tersedia dalam pakan. Jika lemak dalam pakan tidak mencukupi kebutuhan ikan, maka energi untuk beraktivitas diambil dari protein sehingga pertumbuhan menjadi terhambat.

Tingginya kandungan protein pakan tidak selalu menyebabkan peningkatan pertumbuhan. Peningkatan protein pakan tanpa diikuti keseimbangan dengan sumber energi non-protein akan menyebabkan protein digunakan sebagai sumber energi (NRC, 1983 dalam Marzuqi, 2015). Dari semua jenis pakan yang digunakan umumnya sudah memiliki kandungan protein diatas $25 \%$ sebagaimana Meyer dan Pena (2011) menyatakan bahwa kadar protein yang dibutuhkan ikan nila berkisar antara 25-35\%. Namun kandungan protein pakan $\mathrm{C}$ lebih tinggi dibandingankan pakan lainnya yaitu sekitar $39-41 \%$. Jumlah protein ini juga didukung dengan jumlah sumber energi nonprotein yang terdapat dalam pakan sehingga dapat memicu pertumbuhan yang lebih tinggi dibandingkan penggunaan pakan lainnya.

\section{Kelangsungan Hidup}

Ikan yang mendapatkan pakan yang berukuran tepat dengan ukuran bukaan mulutnya akan dapat melangsungkan hidupnya dengan baik (Marzuqi, 2015). Kelangsungan hidup benih ikan nila pada semua jenis perlakuan pakan buatan dapat dilihat pada Gambar 4.

Berdasarkan data yang disajikan pada Gambar 4 diatas dapat diketahui bahwa kelangsungan hidup benih ikan 
nila yang diberi pakan $A, B, C$, dan $D$ berbeda-beda. Kelangsungan hidup tertinggi diperoleh pada benih ikan nila yang diberi pakan $C$ yaitu sebesar $91,11 \%$, sedangkan yang terendah secara berturut-turut adalah yang diberi pakan B, A, dan D. Rendahnya kelangsungan hidup benih ikan nila selama penelitian khususnya pada pakan $\mathrm{D}$ dipengaruhi oleh kandungan nutrisi pakan $D$ yang diduga tidak cukup untuk mendukung kebutuhan pokok ikan. Sebagaimana Harun (2007)

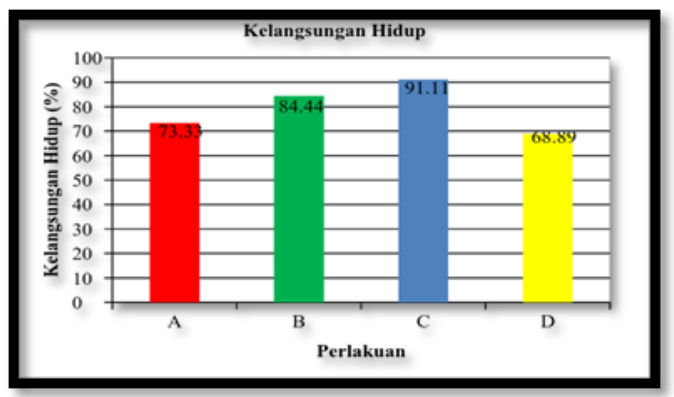

Gambar 4 Kelangsungan Hidup Benih Ikan Nila

menyatakan bahwa kecukupan jumlah dan jenis pakan yang cukup untuk mendukung kebutuhan pokok ikan dapat menunjang kehidupan ikan.

\section{Kualitas Air}

Kualitas air merupakan faktor penting dalam budidaya ikan karena diperlukan sebagai media hidup. Air yang digunakan untuk pemeliharaan benih ikan nila perlu dijaga kualitasnya. Hasil pengukuran kualitas air selama pemeliharaan benih ikan nila (Oreochromis niloticus) menunjukkan bahwa kisaran yang diperoleh masih berada pada batas yang baik bagi kehidupan benih. Data kualitas air dapat dilihat pada Tabel 2.

Pengukuran kualitas air dilakukan setiap seminggu sekali dengan menggunakan alat ukur Monitor Water Checker. Pengukuran dilakukan setiap hari Jumat pukul 16.00 WITA, kualitas air yang diukur yaitu Suhu, $\mathrm{pH}$ dan DO. Sumber air yang digunakan adalah air tawar yang berasal dari Balai Benih Ikan (BBI) Kota Gorontalo, air tersebut kemudian diendapkan dalam sebuah

Tabel 2. Hasil pengukuran kualitas air pemeliharaan benih ikan nila

\begin{tabular}{clll}
\hline Perlak & \multicolumn{3}{c}{ Parameter } \\
\cline { 2 - 4 } uan & \multicolumn{1}{c}{ Suhu } & \multicolumn{1}{c}{$\mathrm{pH}$} & \multicolumn{1}{c}{$\mathrm{DO}$} \\
\hline \multirow{2}{*}{ A } & $26,83-$ & $7,17-$ & $6,00-$ \\
& 26,93 & 7,22 & 6,45 \\
B & $26,85-$ & $7,18-$ & $5,55-$ \\
& 27,19 & 7,41 & 6,04 \\
C & $26,77-$ & $7,16-$ & $5,72-$ \\
& 27,03 & 7,29 & 5,79 \\
D & $26,87-$ & $7,09-$ & $5,55-$ \\
& 27,25 & 7,29 & 5,88 \\
E & $26,86-$ & $7,16-$ & $5,49-$ \\
& 27,37 & 7,46 & 5,82 \\
\hline
\end{tabular}

Sumber: Hasil olahan data primer 2016

akuarium dan wadah box sintetis sehingga dapat digunakan untuk pemeliharaan benih ikan nila.

Air yang digunakan selama pemeliharaan benih ikan nila didukung dengan diterapkan sistem aerasi selama 24 jam, selain itu juga dilakukan pembersihan dasar akuarium dengan cara dishipon yang dilakukan setiap pagi dan sore hari, jumlah air yang diambil dalam kegiatan penyiponan sebanyak $25 \%$ dari total 
air dan sebelum pergantian air. Kegiatan pergantian air dilakukan setelah proses pengukuran panjang dan berat, dengan cara membuang $70 \%$ dari total air yang ada diwadah pemeliharaan kemudian menambahkan dengan air baru. Penerapan sistem sirkulasi air dalam wadah budidaya mengikuti kaidah seperti halnya di perairan terbuka dimana kualitas air selalu dalam kondisi baik.

Tabel 2 menunjukkan bahwa suhu air selama penelitian relatif stabil pada semua wadah pemeliharaan benih ikan nila yang diberikan pakan buatan yang berbeda yaitu antara $26,77-27,37^{\circ} \mathrm{C}$. Sementara $\mathrm{pH}$ berada pada kisaran 7,09-7,46. Menurut Dinas Kelautan dan Perikanan Daerah Provinsi Sulawesi Tengah (2011) dalam Humairani dan Erlita (2012) juga menemukan bahwa ikan nila dapat hidup pada suhu $25-30^{\circ} \mathrm{C}$ dan $\mathrm{pH}$ air 6,5-8,5. Humairani dan Erlita (2012), juga menemukan bahwa nila dapat hidup pada suhu $28,67-29,67^{\circ} \mathrm{C}$ dan $\mathrm{pH}$ 5,8-7. Sementara menurut Kordi dan Tancung (2007), kisaran suhu yang optimal bagi kehidupan ikan nila adalah sebesar $28-32^{\circ} \mathrm{C}$.

Oksigen terlarut merupakan salah satu perameter yang dapat digunakan sebagai pilihan utama menentukan layak tidaknya sumber air untuk digunakan dalam kegiatan budidaya. Nilai oksigen pada pemeliharaan berada pada kisaran 5,49 - 6,45 mg/l, hal ini sesuai dengan pernyataan Sucipto (2004), bahwa ikan nila dapat hidup dalam air dengan kandungan oksigen diatas $3 \mathrm{mg} / \mathrm{l}$, namun untuk meningkatkan produktivitas, maka kandungan oksigen terlarut dalam air sebaiknya dijaga pada level di atas 5 mg/l, hal ini karena pada level di bawah $1 \mathrm{mg} / \mathrm{l}$ dapat menyebabkan laju pertumbuhan lambat.

\section{KESIMPULAN DAN SARAN Kesimpulan}

1. Tiap pakan yang diberikan kepada benih ikan nila memberikan pengaruh yang berbeda-beda. Pertumbuhan mutlak benih ikan nila yang diberikan pakan A, B, C dan D dari segi pertumbuhan panjang mutlak adalah $0.35 \pm 3.07$, $0.4 \pm 3.39, \quad 0.61 \pm 3.89, \quad$ dan $0.26 \pm 2.63 \mathrm{~cm}$, sedangkan untuk pertumbuhan berat mutlak pada tiap pakan adalah pakan $A$ sebesar 1.16+4.05, pakan $B$ 1.45+4.5gram, pakan C $1.85 \pm 4.99 \mathrm{gram}$, dan pakan $\mathrm{D}$ $0.82 \pm 3.34 \mathrm{gram}$. Sementara untuk kelangsungan hidup benih ikan nila pada masing-masing pakan A, B, C dan D sebesar $73.33 \%$, $84.44 \%, 91.11 \%$ dan $68.89 \%$.

2. Pakan yang menghasilkan pertumbuhan dan kelangsungan hidup terbaik bagi benih ikan nila (Oreochromis niloticus) adalah pakan C (PF-1000) yang menghasilkan pertumbuhan panjang mutlak sebesar $0.61 \pm 3.89 \mathrm{~cm} /$ hari $\mathrm{cm}$ dan pertumbuhan berat mutlak sebesar 1.85+4.99 gram serta kelangsungan hidup terbaik 
dengan persentasi sebesar $91,11 \%$.

\section{Saran}

1. Pembudidaya ikan nila sebaiknya menggunakan pakan C (PF1000) untuk mendapatkan pertumbuhan dan kelangsungan hidup optimal.

2. Perlu dilakukan penelitian lanjutan tentang pengaruh pemberian pakan buatan PF1000 dengan dosis yang berbeda guna mengetahui dosis pakan terbaik untuk benih ikan nila (Oreochromis niloticus).

\section{DAFTAR PUSTAKA}

Almaududy, M. 2006. Pengaruh Pemberian Pakan Substitusi Pada Tubifex Sp. Terhadap Pertumbuhan, Konversi Pakan, Dan Sintasan Benih Ikan Balashark (Balantiocheilus melapnoterus bleeker). Skripsi. Fakultas Biologi. Universitas Nasional Jakarta.

Amri, K. 2007. Budidaya Ikan Patin. Penebar Swadaya. Jakarta.

Effendie M. 1997. Metode Biologi Perikanan. Cetakan Pertama. Yayasan Dewi Sri. Bogor. 119 halm.

Fujaya Y. 2004. Fisiologi Ikan. Rineka Cipta. Jakarta

Furuichi M. 1988. Fish Nutrition and mariculture. The general aquaculture Couse. Departement of Aquaculture Biosience, Tokyo University of Fisheries. Tokyo.

Gaspersz, V. 1994. Metode Perancangan Percobaan. Cetakan Kedua. CV. Armico. Bandung.

Gustiano R. OZ. Arifin, A. Widiyanti, L. Winarlin. 2003. Pertumbuhan jantan dan betina 24 famili ikan nila (Oreochromis niloticus) pada umur 6 bulan. Balai Riset Perikanan Budidaya Air Tawar, Bogor.

Halver J E. 2002. Fish Nutrition. Third Ed. Academic Press. New York. $822 \mathrm{pp}$

Hanafiah KA. 2005. Rancangan Percobaan Aplikatif. PT. Raja Grafindo. Jakarta.

Hariadi BA. Haryono U. Susilo. 2005 Evaluasi efisiensi pakan dan efisiensi protein pada ikan kerapu (Tenopharyngodon idella Val yang diberi pakan dengan kadar karbohidrat dan energy yang berbeda. Jurnal Idityos 4 (2):88-92

Harun. 2007. Pengaruh Kadar Protein dan Nisbah energi Protein Pakan Berbeda Terhadap Kinerja Pertumbuhan Benih Ikan Batak (Labeobarbus soro). Tesis. Institut Pertanian Bogor. 
Humairani Z R. dan Erlita. 2012. Pengaruh Umur Larva Ikan Nila (Oreochromis niloticus) Terhadap tingkat Keberhasilan Sel Kelamin Jantan. Lentera: Vol. 12, No. 3.

Linder M. C. 1992. Biokimia nutrisi dan metabolisme dengan pemakaian secara klinis. Department of Chemistry. California State University. Fullerton. Penerjemah Aminudin Paralkasi. UI Press. 781 hal

Marzuqi M. 2015. Pengaruh Kadar Karboidrat Dalam Pakan Terhadap Pertumbuhan, Efisiensi Pakan, dan Aktivitas Enzim Amilase Pada Ikan Bandeng (Chanos chanos Forsskal). Tesis. Program Studi Biologi. Universitas Udayana. Denpasar.

Maskur 2004. Dokumen Standar Prosedur Operasional (Genetik Improvement) Ikan Nila, Pusat Pengembangan Induk Ikan Nila Nasional, Dirjen Perikanan Budidaya Departemen Kelautan dan Perikanan, Jawa Barat: BBAT Sukabumi.

Meyer D E. P. Pena, P. 2001. Ammonia Excretion Rates and Protein Adequacy in Diets for Tilapia Oreochromis sp. World Aquaculture Society. 61-70
Rachmawati D. I. Samidjan, 2013. Efektivitas Substitusi Tepung Ikan Dengan Tepung Maggot Dalam Pakan Buatan Terhadap Pertumbuhan dan Kelulusan Hidup Ikan Patin (Pangasius pangasius). Jurnal saintek Perikanan Vol. 9, No.1.

Sucipto 2004. Broodstock Management lkan Mas dan Nila, Departemen Kelautan dan Perikanan, Jawa Barat: BBAT Sukabumi.

Tarigan R. P. 2014. Laju Pertumbuhan dan kelangsungan hidup benih ikan botia (Chromobotia macracanthus) dengan pemberian pakan cacing sutra (Tubifex sp.) yang dikultur dengan beberapa jenis pupuk kandang. Skripsi. Prodi Manajemen Sumberdaya Perairan. Fakultas Pertanian. Universitas Sumatra Utara.

Trisnawati $\mathrm{Y}$, Suminto, Sudaryono, A. 2014. Pengaruh Kombinasi Pakan Buatan Dan Cacing Tanah (Lumbricus rubellus) Terhadap Efisiensi Pemanfaatan Pakan, Pertumbuhan Dan Kelulusan hidup Lele Dumbo (Clarias gariepinus). Journal of Aquaculture Management and Technology. Fakultas Perikanan dan IImu Kelautan. Universitas Diponegoro. Semarang. 
Wijayanti, K. 2010. Pengaruh Pemberian Pakan Alami Yang Berbeda Terhadap Sintasan dan Pertumbuhan Benih Ikan Palmas (Polypterus senegalus senegalus) Skripsi. Departemen Biologi Akuakultur. Universitas Indonesia.

Yanti Z, Z. A Muchlisin, Sugito. 2013. Pertumbuhan dan Kelangsungan Hidup Benih Ikan Nila (Oreochromis niloticus) Pada Beberapa Konsentrasi Tepung Daun Jaloh (Salix trasperma) Dalam Pakan. Depik, Z (1): 16-19

Zonneveld N, E.A Huisman, J.H. Boom, 1991. Prinsip-prinsip Budidaya Ikan. Gramedia Pustaka Utama. Jakarta. 